\title{
Corporate Payout Policy and Market Capitalization: Evidence from Pakistan
}

\author{
${ }^{*}$ Mian Sajid Nazir1 ${ }^{1}$ Allah Rakha², Muhammad Musarrat Nawaz ${ }^{2}$ \\ ${ }^{1}$ COMSATS Institute of IT, Lahore, Pakistan \\ ${ }^{2}$ University of the Punjab, Lahore, Pakistan \\ *sajidnazir2001@yahoo.com
}

\begin{abstract}
Present study examines the relationship between corporate payout policy and market capitalization by studying payout ratio and dividend yield as measures of payout policy and controlling other variables of size, growth, EPS, Leverage, GDP growth, and Interest rates. Different statistical techniques of correlation, regression, fixed effect and random effect are applied on pooled and panel data to find out the relationship between corporate payout policy and market capitalization. The results show that measures of corporate payout policy, dividend yield and payout ratio has strong negative correlation with market capitalization. Control variables of size and leverage have positive significant correlation with market capitalization while higher earnings per share are leading it negatively and these relationships are statistically significant at various levels of significance. Overall results suggested that the corporate payout policy has significant impact on market capitalization in Pakistan and this notion is consistent with the earlier studies.
\end{abstract}

\section{Keywords: Pay out policy, market capitalization, corporate}

\section{Introduction}

The issue of Payout policy and its effect on firm's stock price had been debated since 1961 after the work of Franco Modigliani and Merton H. Miller with different names and assumptions. But still it's open for discussion as there is contradiction among researchers on this issue. Black (1976) wrote; "the harder we look at the dividend picture, the more it seems like a puzzle, with pieces that just do not fit together."(p.5) He listed it among top ten unresolved problems in the finance literature and we have not an adequate explanation for the observed dividend behavior of the firms. Before the Miller and Modigliani (1961), lots of empirical work has been done to on dividend policy, and there was almost consensus among the researchers that stock price is affected by the corporate payout policy. Graham and Dodd (1951) believe that corporations exist only to pay dividends. But MM's work on dividend policy has changed the previous view that dividend payment is only the purpose of firm's existence. Lot of empirical work has been done in developed, emerging economies and also in Pakistan to find and prove the relationship of corporate payout policy and stock price. Although a lot of studies have been conducted that discuss the relationship of firm's payout policy with different factors, but there is no work on relationship of payout policy and market Capitalization. Only looking at firm's stock price, one cannot say something about the total worth of the firm e.g. if the stock price of a firm is $\$ 50$, one can't estimate the total value of the firm. Market capitalization shows total value of the corporation in the market. As stock price fluctuate, market capitalization has to face fluctuations because market capitalization is dependent on stock prices and calculated by multiplying stock price with no. of shares outstanding. A huge increase or decrease in stock prices may result in overnight changes in value of corporations. Therefore there is need to study and monitor all the elements which may directly or indirectly affect the behavior of stock prices. And with this, corporation has to monitor changes in market capitalization either due to stock price movements or while changing no of shares outstanding. As there is no study on payout policy with reference to market capitalization, Therefore, we have selected this topic for present research. We would use Miller and Modigliani's (1961) irrelevancy theory to build out research hypothesis. According to MM, A firm's value is not affected by its dividend payout policy at all in perfect capital market, Investors are rational in their behavior, and there is perfect certainty in the market. MM made three assumptions to support his view point. These assumptions are perfect market, rational behavior and perfect certainty. First of all, we shall discuss these assumptions in detail; MM described "perfect capital market" as a market where neither buyer nor seller can rule over prevailing prices by his transactions.

Every stakeholder have full reach to all information freely about share's characteristics and prices. Transactions of securities bear no transaction cost, brokerage fee or transfer taxes. Capital gains, dividends, undistributed and distributed earnings have equal tax rates. But there is no such market in the 
world that can fulfill MM's assumptions and can be declare as perfect capital market. Because there are transfer taxes, brokerage fees and transaction costs in all markets. There are also differences in tax rates on capital gains and dividends. And all the stakeholders (e.g. managers, firm's shareholders and potential investors) of market don't have free and equal access to the information. Generally it is observed that management only convey positive information about the current and future prospects of the firms to the market, while any negative information is set aside for maintaining good perception about the firm. Another condition of perfect capital market is that no seller or buyer of the securities may affect the stock prices by his transaction. But it is observed that most stock of the companies are held by large investors, (e.g. investment institutions, wealthy people and by the people who are part of management), these investors can affect the prices of the stocks by their transactions. Second assumption of the dividend irrelevancy theory is about rational behavior. MM describe "Rational behavior" as the behavior when people only desire an increase in their wealth either form of cash or increase in stock value. It means that the investors only want an increase in their wealth either through capital gains or dividend payments. But different investors have different behavior about dividends and capital gains. Some investors want immediate reward of their funds in the form of dividend payments while others prefer capital gains. Therefore, it looks very much difficult to be fulfilled the assumption of rational behavior in the real world. Third assumption of the dividend irrelevancy theory is regarding perfect certainty. MM described "Perfect certainty" as situation when all investors are fully assured about future earnings and investment plans of all corporations. But there may be very few large and stable firms operating in developed economies that can fulfill this assumption up to some level. But all firms of the developed and emerging economies may not be sure about their future profits and investment plans. Therefore this assumption could be true to some extent. In Pakistan, there is uncertainty prevailing everywhere as per political, economic and security conditions in Pakistan. Investors are shifting their business in foreign countries due to many reasons like shortage of electricity and gas, security conditions e.g. a large portion of our textile sector has been moved to Bangladesh due to bad economic conditions in Pakistan. New investors are not coming to Pakistan due to security conditions, poor infrastructure, corruption, bad governance etc. All investors of Pakistan are not rational as per MM's assumption; all of them do not prefer capital gains on dividend payments. There are some small investors who needs regular stream of funds to meet their needs. There exist large investors who can influence the current stock prices by their transactions. All the investors don't have complete information about the firm's operations. There are also difference tax rates on capital gains and dividends and transactions cost, taxes also exist in capital market of the Pakistan. Therefore, by keeping in view this discussion, the present study is very important in its nature to investigate the determinants of market capitalization of a particular stock, and we can build our hypothesis that, dividend payout policy has effect on the market capitalization of the firm in Pakistan because assumptions made by MM are not fully met in our market. The research objective of present study is to find either corporate payout policy may have an impact on market capitalization or not, and if there exist some association then what is the direction of this relation. Is market capitalization only influenced by corporate payout policy? Or there're other factors which may also affect market capitalization of individual stocks. In chapter two and three, we will go through the theories related to payout policy and stock price movement and empirical work done on this issue. Chapter four and five include research design and results and discussion of our research.

\section{Theoretical Framework}

Bird in Hand Theory: The founder of the bird in the hand theory was Graham and Dodd (1951) and it was further explained by Harkavy (1953) Gordon (1959). Graham and Dodd (1951) reported that "the sole purpose for the existence of the corporation is to pay dividends". Firms with high payout policy enjoy higher stock prices. According to this theory, shareholders or new investors always desire current dividends in spite of future expectation of capital gain for minimizing the uncertainty risk related to future cash flows. The conventional argument in favor of bird in hand theory is the idea that dividends payments decreases risk because these provide cash inflows for shareholders. Shareholder can also generate cash inflows by selling out shares in the stock market. But for doing this they have to bear trading cost in stock market. This extra cost is saved if firms payout dividends. Besides this, dividend payments also reduce the risk of uncertainty which is linked with future cash flows. In terms of the discounted dividend equation of firm value, the idea is that the required rate of return demanded by investor's increases with the plough-back ratio. Although the increased earnings retention brings about higher expected future dividend, this additional dividend stream is more than offset by the increase in the discount rate. This argument overlooks the fact that the risk of the firm is determined by its investment decisions and not by how these are financed. The required rate of return is influenced by the risk of the 
investments and should not change if these are financed from retained earnings rather than from the proceeds of new equity issues.

Dividend Irrelevancy Theory: Dividend Irrelevancy theory was presented by Miller and Modigliani (1961), they argued that firm's basic earning power and business risk determined its value. And firm's value is not affected by its dividend payout policy at all in perfect capital market, Investors are rational in their behavior, and there is perfect certainty in the market. MM made three basic assumptions and describes them as "perfect capital market" is a market where neither buyer nor seller can rule over prevailing prices by his transactions. Every stakeholder have full reach to all information freely about share's characteristics and prices. Transactions of securities bear no transaction cost, brokerage fee or transfer taxes. Capital gains, dividends, undistributed and distributed earnings have equal tax rates. "Rational behavior" as the behavior when people only desire an increase in their wealth either form of cash or increase in stock value. And "Perfect certainty" is a situation when all investors are fully assured about future earnings and investment plans of all corporations. In simple words, we can say that the firm's value depends only on the profits generated by its assets, not how those profits are split between retained earnings and dividends. They set the assumption that managers and investor have identical information about future earnings and dividends of the firms. Firm's stock price or cost of capital is not affected by dividend payout policy. So, if Dividend Payout Policy has not any significant effect, then it is irrelevant.

Agency Theory: Then Jenson \& Meckling (1976) presented a new theory named Agency Theory. According to this theory, Management could be incapable to maximize shareholders' wealth. Managers can use retained earnings in bad project or projects with negative NPV due to their own interests or incapability. Therefore large part of earning should be paid as dividend so there should be less money in the hands of managers who can use this money in non-profitable projects. The basic problem arises due to the separation of control and ownership which results agency conflicts. A furtherer explanation of agency theory was presented by Easterbrook (1984) and argued that payment of large portion of earning can solve the issue of combined actions that tends to lead to under monitoring of the corporations and its managers. So, Payments of dividends and subsequent raise of external finance encourage analysis of the firm by financial intermediaries such as investment banks, regulators of the stock exchange and investors. This monitoring minimizes agency costs and results in an increase in firm's market value. Jenson (1986) argued that if large portion of earning is paid as dividend, firm's value would be increased because there would be less free cash flow in hands of manager. And they would have no funds available to invest in projects of their own interests.

Tax effect Theory: Miller \& Scholes (1978) presented Tax Effect Theory which argues that difference of tax rates on dividend income and capital gains make clientele. Taxable investors can be indifferent to dividends even when the tax regime favors capital gains. Keeping in mind following points, investors may prefer to low dividend payout to high dividend payout; i) the tax rate on capital gains are lower as compared to dividends. Therefore Large investors who own most stock of the firm and are in high tax brackets will always prefer firms with low payout policy .ii) Capital gains taxes are payable only when stock is being sold. By considering time value effects, a dollar of tax paid in future has a lower effective cost than a dollar paid today. iii) There is no capital gain tax payable towards beneficiaries if a person held the stock until his death. Investors choose firms regarding their preference of dividends and capital gains. Individuals in low tax brackets may prefer firms which pay high dividends. No firm can increase its value by changing its dividend payout policy as there are many firms to satisfy all types of investors.

Signaling Theory: Signaling Theory argue that as all stockholders (e.g. managers, stock holders and potential investors) have not equal information about the earning of the firm. In this situations management has to pay large portion of earnings as dividends to signal the stakeholders that firm is generating healthy profits out of its assets. According to the signaling hypothesis, announcements of dividend convey signal to the investors regarding future profits of the firm. To hold third hypothesis, management should have some information regarding prospects of the firm, and managers are allowed to convey this information to market. And signal about future earnings of the firm should be true. Firms should not convey false signal about earning of the firm by increasing dividends only. As dividend payments would increase, it would send the signal that firm would have high profitability in future, as a result stock price of that firm will be high. On the other side, a decrease in dividend payment s would be consider as the low profitability in future, as a result stock price will go down. The most work on signaling theory was done by Bhattacharya (1979), John \& Williams (1985), and they argued firm may be 
undervalued when investor has to meet their liquidity needs. If investor sells their holdings at that time, then wealth transfers to new stockholders. However, firm can cater this situation by paying out dividends. The involvement of dissipative cost increases the credibility of the signaling through dividends. In Bhattacharya's model signaling cost is the transaction cost related with external finance, in John and William's model the dissipative cost is the tax penalty on dividends relative to capital gains, in Miller and Rock's (1985) model the dissipative signaling cost is the misrepresentation in the optimal investment decision. So, dividend payment can be used for signaling their prospects by firms. Weak firms can't send wrong signal due to dissipative cost involved. The main criticism on signaling theory is that why dividend announcement are used for signaling when other cheap means like share repurchase are available.

Life Cycle Theory: Firms have different phases during its life cycles from introduction to growth, maturity and decline. Firms follow different payout policies at each stage. When the firms are at introduction stage and earning less, they are not in a position to payout dividends. At growth stage, although firms earnings are high, but there is need of funds to invest in growth projects. Therefore, most firms payout less. At maturity stage, when firms have fewer or no growth opportunities and stable earnings, then firms payout most of their earnings as dividends if they don't have any other projects to invest. According to life cycle theory, firms follow different payout policy at each stage of life cycle. Dividend paying firms tend to be mature and face low stock price volatility. Most work on this argument was done by Lease et.al (2000) and Fama and French (2001), they argue that by decreasing transaction costs on the sale of shares for the purpose of consumption, the opinion about dividend payments benefits can be changed. By large holding of firm's stock by management who prefer capital gains to dividends and by introducing good corporate governance technologies that lower the benefits of dividends in controlling the agency problems between stockholders and managers.

Catering Theory: According to catering theory given by Baker and Wurgler (2004), decision whether to payout dividend or not should be determined by the current investors demand. They argued that managers should provide incentives to the stock holders keeping in view their needs and wants and should pay dividends when investors prefer those firms which pay dividends and should keep the earnings with the firm when investors prefer capital gains to dividends. There are three main ingredients of the catering theory; first, it hypothesizes a source of ignorant demand of investor for dividend paying firms. Second, limits on arbitrage permit this demand to influence recent share prices. Third, managers sensibly consider the short run advantages of catering to the existing mispricing against the long run costs and then make the dividend payment decision. The empirical work regarding catering theory shows that rates of omission or initiation of dividends are dependent upon the prevailing dividend premium. There is need to compare existing stock prices of dividend payer firms with those firms which are not currently paying dividends. To test these hypotheses, four share price base measures were introduced to observe demands of investors about payers or nonpayer firms. The results show that nonpayer firms likely to start paying dividends when there is high demand of dividends and other firms which are paying dividends stop paying dividend at the time of low demand. This theory is only argued that firms should pay dividend or not, it does not tell how much dividend should pay. Once a firm start paying dividend, it is up to the management to raise or reduce the dividends according to earnings of the firms.

\section{Literature View}

Studies in Developed Countries: Harkavy (1953) found positive association between earnings and stock price. The larger the portion of net earnings would be paid as dividend, the higher would be the share price of those firms. He examined that the stock prices tend to be varying directly in the proportion to the distribution of earnings in a given time frame. It means if there are two stocks of similar firms, investor would pay high price for the stock of those firms whose payout ratio is high. This proposition suggested giving the instant return to the shareholder against the utilization of his funds. He also reported that over the years, stock prices of those firms tend to be high, which kept the larger portion of earnings as retained earnings. Gordon (1959) found that stock price are strongly affected by dividend payments than retained earnings and a stock' s required rate of return increases as the fraction of retained earnings due to uncertainty of future earnings. Fisher (1961) found that stock prices are widely influenced by dividend payout policy as compared to retained earnings. Ball et al. (1979) found that a firm's value is affected by dividend payout policy of the firms. Friend and Puckett (1964) found little evidence that a dollar of dividends has several times the impact on price of a dollar of retained earnings. They also found that stock price of the firms, having no or less growth opportunities are affected by dividend payments, but dividend payments have less or no impact on stock price of the firms having larger growth potential. 
Diamond (1967) found little evidence that investor prefer dividends to retained earnings. But investors prefer retained earnings in high growth industries while dividends are ideal in low growth industries. Litzenberger and Ramaswamy (1982) found that a nonlinear positive relationship exists between stock return and firm's dividend yields. The expected dividend yield can be predicted by the information available to the investors. Rozeff (1982) found that if large stocks of the firms are held by outside shareholder, they want higher dividend payout and firms with less ownership dispersion and large inside ownership have less benefit of dividends to reduce agency cost problems. Baker et.al (1985) reported that payout policy of the firms have significant impact on the share price movements of the firms. Baker and Powel (1999) examined that managers take into account the consistency in dividend payments while deciding the payout ratio of the firm.

Baskin (1989) found a significant and dominating negative relationship between dividend yield and stock price volatility. Allen \& Rachim (1996) reported that a significant negative relationship exists between the dividend payout ratio and share price volatility and a significant positive relationship exist among share price volatility and leverage. It means that stock price is not affected by dividend yield while dividend payout ratio, earnings volatility, leverage, size of the firm is major determinants of stock price. Conroy et al. (2000) found that earnings of the firm dominate to explain stock price movements, and current year's dividend has no significant impact on share prices but forecast about next year's dividend has a small but significant impact on share price movements. Hussainey et. al (2011) found that a significant negative relation exists between dividend payout ratio and share price volatility of the firm and there is a negative relation between dividend yield and stock price volatility. They propose the payout ratio as the main determinant of share price volatility. Debt and size has highest correlation with stock price volatility among control variable. There exist significant negative relations between size and share price volatility. They also found that debt has a significant positive relationship with share price volatility which means that if a firm is more leveraged, its stock price would be more volatile. And there is a significant negative relationship between the size and share price volatility which means as a firm is larger, its share price volatility is less.

Studies in Emerging Economies: Abor and Bokpin (2010) found Stock market capitalization and profitability have significant impact on payout policy. Firms with high market capitalization payout low dividends because it may have better growth potential and needs fund to finance this growth. Naceur et al. (2006) found that there is inconsistency in dividend payments, last year's dividend payout ratio and current year's earnings are major determinants of payouts of the firms, and liquidity is negatively correlated with dividend policy. Firms with consistent earning and high profitability tend to pay large dividends, firms having growth opportunities pay more dividends to catch the attention of new investors, and dividend policy is not influenced by ownership structure due to very few agency conflicts. Rashid and Rehman (2008) found that there is non-significant positive relationship between share price volatility and dividend yield. Anil \& Kapoor (2008) found that only liquidity and risk determines the dividend payout policy. Okpara (2010) found that earnings have inverse association with payout ratio as they are retained for growth. Last year's dividend and current ratio imply positive effect on dividend yield and payout ratio. Firm having free cash is likely to increase dividends. Farooq et al. (2012) show that there is a significant negative association between payout ratio and share price volatility and significant positive association between payout ratio and stock returns in constant growth period.

Studies in Pakistan: In the context of Pakistan, Nishat \& Irfan (2003) found that dividend payout policy has significant impact on stock price volatility. Payout ratio has significant effect at lower level of significance. The earnings volatility effect is significant and negative. The size effect is negative during 1981 to 1990, but it becomes positive during 1990 to 2000.Naeem and Nasr (2007) reported that the payout ratio of most firms in Pakistan is very low. Leverage, liquidity and investment opportunities are negatively correlated with dividend payouts. Firms with higher net income payout large dividends and current year's earnings are major determinant of payout policy. Larger financial firms have high payout ratio in when they have low growth opportunities and non-financial firms have to invest more funds in fixed assets that have negative impact on their payouts. Ahmed \& Javid (2009) found that the size and market capitalization have negative effect on payout policy. Following Nishatand Irfan (2003), Nazir et. al (2010) found that there exist strong significant relationship between dividend payout policy and stock price volatility of KSE listed firms. Payout ratio has significant effect at lower level of significance but the impact of dividend yield to share price volatility enlarged. The leverage and size created negative and insignificant impact on share price volatility. Moreover, Imran (2011) found a negative association between payout and cash flows which propose that firms plough back its extra cash. Asghar et. al (2011) 
found that dividend yield and growth in assets has strong relationship with stock price movements. Asif et. al (2011) that leverage has significant impact on dividend per share but negative effect on dividend payouts, and dividend yield has positive effect on dividend policy while there is no impact of change in earnings on dividend payout policy. Khan et al. (2011) examined the managerial view about payout policy in Pakistan and found that the payout policy decisions are similar to developed markets. They also found that firm's liquidity and current year's earning are the major determinants of payout policy and current dividends are not affected by past year's dividends. Although, there are various studies who investigated corporate payout policy on stock prices of firms, no single study has tried to establish its relationship market capitalization of individual stocks. This provides us a huge gap and rationale for conduction of the current study. In this regards, dividend yield and payout ratio are used as the measures of corporate dividend policy. Based upon the review of literature discussed above, our proposed hypothesis to be tested is as follow;

$\mathrm{H}_{0}=$ Dividend yield has no effect on market capitalization of the firms.

$\mathrm{H}_{1}=$ Dividend yield has significant effect on market capitalization of the firms.

$\mathrm{H}_{2}=$ Payout ratio has no effect on market capitalization of firms.

$\mathrm{H}_{3}=$ Payout ratio has significant effect on market capitalization of firms.

\section{Research Design}

Population and Sample: This study examines the effect of corporate payout policy on its market capitalization. For this purpose, we have selected 68 firms from nonfinancial sector of Pakistan listed at KSE-100 index for the period of five years from 2006 to 2010. KSE-100 index firms represent the 85\% market share. There are 75 firms of nonfinancial sector listed at KSE-100 index. Out of those 75 firms, Researchers excluded seven firms from sample which are merged or dissolve or go bankrupt or established after 2006 or delisted during our research period. Data of our sample companies has been collected from various secondary source i.e. Karachi Stock Exchange website, State Bank of Pakistan website, official websites of firms, and financial statement of the firms. Explanatory variable data has been taken from annual reports of the firms and "Balance Sheet Analysis" (2005-2010) published by State Bank of Pakistan. The yearly stock price data is taken from the website of pakfinance.info and analysis reports of Karachi stock exchange.

The Model: Different statistical Techniques are applied on our panel data to measure the effect of corporate payout policy on its market capitalization. We use fixed effect and random effect techniques for this purpose. We use following regression model to measure the effect of dividend payout policy and market capitalization. The model is similar to that of Nazir et al (2010), Allen and Rachim (1996), Nishat (1992), and Baskin (1989)

$\mathrm{MC}=\mathrm{a}_{1}+\mathrm{a}_{2} \mathrm{DYj}+\mathrm{a}_{3} \mathrm{PR}_{\mathrm{j}}+\mathrm{e}_{\mathrm{j}} \ldots . .(\mathrm{i})$

Allen and Rachim(1996) found that there is positive relation between stock price volatility and dividend yield, and a negative relation between stock price volatility and dividend payout. The close relation among stock price volatility and dividend policy may cause some problem as there are a number of factors that influence dividend policy. In this study, there are number of factor which can affect Market Capitalization. We include those factors as control variable in our model for limiting their impact.

$\mathrm{MC}==\mathrm{a}_{1}+\mathrm{a}_{2} \mathrm{DY}_{\mathrm{j}}+\mathrm{a}_{3} \mathrm{PR}_{\mathrm{j}}+\mathrm{a}_{4} \mathrm{LVRG}_{\mathrm{j}}+\mathrm{a}_{5} \mathrm{Growth}_{\mathrm{j}}+\mathrm{a}_{6} \mathrm{EPS}_{\mathrm{j}}+\mathrm{a}_{7} \mathrm{Size}_{\mathrm{j}}+\mathrm{a}_{8} \mathrm{I}_{\mathrm{j}}+\mathrm{a}_{9} \mathrm{GDP}_{\mathrm{j}}+\mathrm{e}_{\mathrm{j}} \ldots .$. (ii)

MC is market capitalization, a is constant term, DY is dividend yield, PR is payout ratio, LVRG stands for leverage, growth for asset growth, EPS is earning per share, size is size of the firm, I stands for interest rate, GDP is taken as GDP growth rate and e stands for error term.

\section{Measurement of Variables}

- Market Capitalization (MC) has been taken as dependent variables. Market Capitalization is being calculated by multiplying stock prices during the year with number of shares outstanding of the firm.

Market Capitalization $(\mathrm{MC})=$ current stock price $*$ no. of shares outstanding

- Payout Policy has been taken as independent variable, dividend yield and payout ratio of the firm are used as the measure of corporate payout policy. 
- Payout ratio (PR) has been taken as Independent variable. It is calculated by dividing the total cash dividend (by adding all cash dividends paid quarterly, half yearly or interim dividends etc.) distributed among stock holder during the year to total earning of the company for current period. Following Nishat and Irfan (2003), the present study measures payout ratio as:

Payout Ratio = Total cash Dividend distributed in a year $/$ Total earning in a year

- Dividend Yield (DY) is our independent variable. Dividend yield is calculated by adding up all cash dividends paid quarterly, semiannually or annually and dividing it by average market price of the shares of the firms. Following Nishat and Irfan (2003), the present study measures dividend yield as:

Dividend Yield (DY) = sum of all cash dividends/ average market value of common stock

Following factors may also affect the stock market capitalization of the firm, so these factors have been taken as control variable in our research. Nazir et al. (2010) argued that Interest rates(I) are inversely related with stock market capitalization. As interest rates increases in the economy, people transfer their funds to the banks and with a decrease in interest rates, people invest in stock of the companies in hope of high yield. Six month KIBOR is converted to annual rate for our analysis.

- Gross Domestic Product (GDP) has positive relation with stock market capitalization. As GDP increases, per capita income increases, and people have more saving to invest. Five years GDP growth is taken for present study.

- Earnings per share (EPS) if firm is earning profits, it is able to pay dividend. Baker et al. (1985) found that an important determinant of dividend payout is the predicted level of future earnings. Conroy et al. (2000) reported that earnings of the firms dominate to explain share price movements in Japan.

- Assets Growth (Growth) Bhattacharya (1979) wrote that the high growth firms are smoother to pay their dividends to shareholders. Asset growth is calculated by subtracting Total assets of previous year from total assets of Current year and dividing it by total assets of Last year.

Asset Growth $=($ Total assets of CY - Total assets of LY) / TA of LY

- Leverage (LVRG) has negative effect on dividend payouts. Rozeff (1982) found that highly leverage firm pay less dividends to avoid the cost of raising external capital. Leverage is calculated dividing total debt of the firms by total asset.

Leverage $=$ Total debt $/$ Total Assets

- Size (Size) Large firms are often more diversified in their activities and are best choice for investors. Scott \& Martin (1975) found that the size of the firm may affect its payout policy. Baskin (1989) found that firms with a more dispersed body of shareholders may be more disposed towards using dividend policy as a signaling device.. Size is calculated dividing total shareholder's equity (common stock, retaining earning, and reserves) by dividing outstanding shares of the firm. As there appear some negative values, so we take square root of it and then find natural log of the size to use in calculation.

\section{Results and Description}

Descriptive Analysis: Our descriptive analysis includes the measurement and analysis of central tendency (i.e. by mean and median), dispersion (by maximum, minimum and standard deviation) and distribution (by skewness and kurtosis) of data. We have calculated mean, median, standard deviation, skewness, kurtosis, minimum and maximum of all the variables of 68 nonfinancial companies of KSE-100 index for the period of five years through 2006-2010.

Table 1: Descriptive Analysis

\begin{tabular}{llllllll}
\hline Variables & Mean & Median & $\begin{array}{l}\text { Standard } \\
\text { Deviation }\end{array}$ & Skewness & Kurtosis & Minimum & Maximum \\
\hline MC & 10.5305 & 10.4782 & 2.0001 & -0.033 & 0.139 & 4.6952 & 15.7081 \\
DY & 0.0451 & 0.0296 & 0.0727 & 6.817 & 72.265 & 0.0000 & 0.9410 \\
PR & 0.4478 & 0.3038 & 0.7612 & 6.318 & 55.338 & -0.8250 & 8.5596 \\
Size & 8.0725 & 7.8529 & 4.2321 & 0.047 & 1.110 & -3.0883 & 24.0161 \\
EPS & 25.3108 & 10.4823 & 57.0489 & 5.294 & 36.448 & -87.5179 & 531.5707 \\
Growth & 0.2727 & 0.1336 & 0.8905 & 10.297 & 124.211 & -0.8812 & 12.2152 \\
LVRG & 0.5454 & 0.5694 & 0.3102 & 3.011 & 22.030 & 0.0237 & 3.1482 \\
GDP & 0.0510 & 0.0580 & 0.0184 & -0.650 & -1.056 & 0.0200 & 0.0700 \\
I & 0.1079 & 0.1076 & 0.0069 & 0.069 & -1.297 & 0.0983 & 0.1179 \\
\hline
\end{tabular}


In Table 1, Mean value of our dependent variable of market capitalization (MC) is 10.5305 and median is 10.4782 with the standard deviation of 2.0001. Minimum and maximum values of MC are 4.6952 and 15.7081 respectively. Skewness in our dependent variable is -.033 which means frequency distribution of MC is negatively skew and. Kurtosis value is .139 which is less than 3 that means curve of kurtosis is very peaked which is called platykutric. Independent variable dividend yield (DY) carries the mean value of .0451 with the standard deviation of .0727 . Minimum value is .0000 , maximum value reaches to .9410 , and middle value (median) of DY is .0296. Skewness is 6.318 which show that frequency distribution is positively skewed. And value of Kurtosis is 72.265 which is greater than 3 which means curve of kurtosis is high which is called leptokutric. Mean for our independent variable Payout ratio (PR) is .4478 with the standard deviation of .7612. Minimum and maximum value ranges from -3.0883 to 24.0161 with the median of 7.8529. Skewness value is 6.318 which show data is positively skewed. Kurtosis is 55.338 which mean curve of kurtosis is high. Means value of our control variable size is 8.0725 with the standard deviation of 4.2321. Minimum value of the Size is -3.0883 and maximum value is 24.0161 with the median of 10.4823. Frequency distribution is positively skew with the value of .047. Kurtosis curve is peaked with the value of 1.110. Control variable earnings per share have mean value of 25.3108 with the standard deviation of 57.0489. Minimum and maximum values are -87.5179 and 531.5707 respectively with the median of 10.4823 . Skewness of 5.294 shows the positively skewed frequency distribution. Value of kurtosis is 36.448 showing high peak of the curve. Growth has mean value of .5454 with the standard deviation of .3102. Minimum and maximum values are -.8812 and 12.2152 respectively with the median of .1336. Frequency is positively skew with the value of 10.297. And curve of kurtosis is very high with the value of 124.211. Leverage has the mean value of .5454 with the standard deviation of .3102 . Minimum and maximum values are .0237 and 3.1482 with the median of .5694. Skewness and Kurtosis values are 3.011 and 22.030 respectively that shows frequency distribution is positively skewed and has high peak.GDP variable of economy has mean value of .0510 with the standard deviation of .0184 . Minimum and maximum values range from .0200 to .0700 and the value of median is .0580 . Frequency distribution is negatively skewed with the value of -.650 . Kurtosis value is -1.056 shows the flatness of the curve. Mean value of interest rate is .1079 and value of median is .1076 with the standard deviation of .0069. Minimum and maximum values are .0983 and .1179 respectively. Frequency distribution is positively skewed with .069 coefficient of skewness. Kurtosis of -1.297 shows that curve of kurtosis is at peak.

Regression Analysis: We use regression techniques on pooled data and panel data of our 68 firm from non-financial sector of KE-100 index for the period of five years from 2006-2010. We regressed our dependent variable Market Capitalization (MC) against independent variables of Payout ratio (PR) and dividend yield (DY) are independent variables. We use size, EPS, Growth, LVRG, GDP and I as control variables. Following are the results of our correlation and regression techniques on pooled and panel data respectively.

Pooled Data: We apply correlation and regression techniques on five years average values of our pooled data. Normality test are applied on pooled data to check its normality. We draw normality curve and Shapiro wilk's normality test and find our data is normal. In Table 2, we apply correlation technique on pooled data. We exclude GDP and I from the table, because values of GDP and I are same for all 68 observations, as average values of GDP and I are same in whole data, we omit these variables. DY carries negative correlation with MC which is significant at .01 levels. PR is negatively associated with MC having value of .254 which is significant at .05 levels. Significant level decrease from .01 to .05 in case of PR and MC in pooled data. Size owns positive correlation with MC having value of .435 and .05 confidence levels. EPS has negative significant association with MC having value of .453 with .05 significant levels. EPS also have negative correlation with Size having values of .245 at .005 levels of significance. Growth carries negative correlation with MC having value of -.060 which is not significant. LVRG has positive correlation with MC at .05 confidence levels. LVRG is also inversely correlated with PR at .05 significant levels. Major change we observe in our pooled technique is that we have found a significant negative relationship which leads to reject our null hypothesis and prove that DY has significant effect on MC. PR results also rejected our null hypothesis and prove that PR has significant effect on corporate payout policy. Panel technique results show that corporate payout policy has significant effect on its market capitalization. Our analysis on prove that this relationship negative which means decrease in payout ratio leads to increase in stock prices. Table 3 shows the relationship between independent variable DY and MC is negative having value of -10.4992 at .05 level of significant. Control variable size has positive relationship with MC. This shows that big size firms have high market capitalization. EPS has negative significant relationship with MC. It means decrease in earnings leads to high market capitalization. This results show that 
Pakistani investors prefer capital gains as compared to earnings. Growth has negative relationship with market capitalization which is insignificant. LVRG carries positive significant relationship with MC that shows that increase in debt leads to high MC because funds are used in profitable projects which send positive signals in the market.

Table 2: Pearson's Correlation using Pooled Data

\begin{tabular}{lllllll}
\hline Variables & MC & DY & PR & Size & EPS & Growth \\
\hline DY & $-.315^{* *}$ & & & & & \\
PR & $-.254^{*}$ & $.741^{* *}$ & & & & \\
Size & $.435^{* *}$ & .039 & -.054 & & & \\
EPS & $-.453^{* *}$ & .022 & .054 & $-.245^{*}$ & & \\
Growth & -.060 & .164 & -.099 & -.110 & -.050 & \\
LVRG & $.264^{*}$ & -.210 & $-.275^{*}$ & -.154 & -.001 & .206 \\
\hline
\end{tabular}

are significance levels at $1 \%$, and $5 \%$ respectively.

Table 3: Relationship between dependent variable MC and other variables using pooled data

\begin{tabular}{lllll}
\hline Variables & Coefficient & Coef. Std. Err. & t-value & p-value \\
\hline DY & $-10.4992^{* *}$ & 4.4127 & -2.38 & 0.020 \\
PR & 0.5372 & 0.6324 & 0.85 & 0.399 \\
SIZE & $0.1831^{* * *}$ & 0.0431 & 4.24 & 0.000 \\
EPS & $-0.0122^{* * *}$ & 0.0032 & -3.74 & 0.000 \\
Growth & -0.1174 & 0.5181 & -0.23 & 0.821 \\
LVRG & $2.3308^{* * *}$ & 0.7780 & 3.00 & 0.004 \\
Constant & $8.4628^{* * *}$ & 0.7039 & 12.02 & 0.000 \\
\hline
\end{tabular}

are significance levels at $1 \%, 5 \%$, and $10 \%$ respectively.

Our panel data exist on 340 observations of 68 firms for the period of five years through 2006-2010. Firstly, we applied normality curve and Shapiro wilk's test techniques to check the normality of data and found that our data is normal. Now we apply correlation and regression techniques of fixed and random effect model to measure the relationships among our variables. Table 3 shows the Correlation among all variables related to our study. DY's Correlation with MC is negative having value of -.050 , but it is insignificant which support our null hypothesis $\left(\mathrm{H}_{0}\right)$ and prove that dividend yield has no effect on corporate payout policies. PR has significant negative correlation with MC having value of -.141 with $99 \%$ confidence level which reject our null Hypothesis $\left(\mathrm{H}_{3}\right)$ and prove that Payout ratio has significant impact on market capitalizations of the companies.

Table 3: Pearson's Correlation using Panel Data

\begin{tabular}{lllllllll}
\hline Variables & MC & DY & PR & Size & EPS & Growth & LVRG & GDP \\
\hline DY & -.050 & & & & & & & \\
PR & - & $.669^{* *}$ & & & & & & \\
Size & $.141^{* *}$ & .100 & -.030 & & & & & \\
EPS & $.390^{* *}$ & .049 & .002 & - & & & & \\
Growth & - & .102 & .002 & $.206^{* *}$ & - & & & \\
LVRG & $.361^{* *}$ & .045 & - & -.045 & .003 & -.058 & & \\
GDP & -.022 & - & $.118^{*}$ & $-.115^{*}$ & .000 & -.077 & -.053 & \\
I & $.186^{* *}$ & $.147^{* *}$ & -.007 & -.020 & .003 & .031 & .034 & - \\
& $-.129^{*}$ & $.118^{*}$ & -.026 & .049 & .024 & & & $.766^{* *}$ \\
& .079 & & & & & & &
\end{tabular}

are significance levels at $1 \%, 5 \%$, and $10 \%$ respectively.

DY and PR as measures of Payout Policy have multicollinarity problem with having positive value of .669 which is significant at $99 \%$ level of confidence. We have multi collinarity diagnose test and found that multicollinarity between DY and PR does not create some problem. Therefore we ignored this issue. Our control variable Size is positively correlated with MC having 99\% confidence level. Its value is .390. Size of the firms has strong impact on market Capitalization. EPS carries negative significant correlation with MC having -.361 value. EPS has also significant negative correlation with Size carrying value of _.206 at .01 significant levels. Growth doesn't have significant relation with MC. LVRG carries .186 value proving positive relation having 99\% confidence level. LVRG also own significant correlation with PR and Size 
having values of -.118 and -.115 respectively. GDP holds positive correlation with MC having value of .129 at $95 \%$ confidence level. But GDP has significant negative correlation with DY. Interest rates don't have any relationship with MC but it carries significant positive correlation with DY and significant negative correlation with GDP. GDP and Interest have multicollinarity issue with the value of -.766 which is greater than .5.By applying multicollinarity diagnose test, we found that multicollinarity between GDP and I creates serious problem. Therefore, we run separate regression models using GDP and I.

Fixed Effect Model and Random Effect Model: We use fixed and random effect models of regression on panel data. GDP and I have serious multicollinarity issues, so we have run two models to mitigate this problem. In Table 4, we excluded control variable I and in table 5 we excluded control variable GDP. We apply Hauseman's test on our fixed and random effect models, which support the results of fixed effect model are more reliable as compared to random effect model. Table 4 gives the results of fixed and random effect models excluding control variable of Interest. In fixed effect, DY, Growth and GDP have inverse relationship with MC while remaining variables show positive relationships. Values of EPS and GDP are significant. Values of DY, PR, Size, EPS, Growth, LVRG, and GDP are -.848, .011, .025, .004, -.025, .049 and -14.398 respectively. In random effect model, DY, PR, EPS, Growth, and GDP have negative relationship with MC while values of Size and LVRG are positively related with MC. In random effect model, size and GDP has significant values. Values of DY, PR, Size, EPS, Growth, LVRG, and GDP are -1.147, $-.017, .121,-.002,-.004, .291$, and -13.781 respectively. Table 5 gives the results of fixed and random effect models excluding control variable of GDP. In fixed effect, PR, DY and Growth have inverse relationship with MC while remaining variables show positive relationships. Values of EPS and I are significant. Values of DY, PR, Size, EPS, Growth, LVRG, and I are -.266, - .015, .018, .003, -.003, .107 and 21.675 respectively. In random effect model, DY, PR and EPS have negative relationship with MC while values of Size, Growth, LVRG and I are positively related with MC. In random effect model, size and I has significant values. Values of DY, PR, Size, EPS, Growth, LVRG, and GDP are -.586, -.044, .120, -.002, .016, .355 and 19.568 respectively. Overall results are consistent with over above findings but there is difference of significant level. We apply Hauseman's test that shows that results of fixed effect model are reliable as compared to random effect model.

Table 4: Fixed Effect and Random Effect model (Excluding Interest)

\begin{tabular}{|c|c|c|c|c|}
\hline & MODEL-FE & & MODEL-RE & \\
\hline & $\mathrm{b} / \mathrm{se}$ & p-value & $\mathrm{b} / \mathrm{se}$ & p-value \\
\hline \multirow[t]{2}{*}{ DY } & -0.848 & 0.311 & -1.147 & 0.166 \\
\hline & $(0.83)$ & & $(0.83)$ & \\
\hline \multirow[t]{2}{*}{ PR } & 0.011 & 0.867 & -0.017 & 0.805 \\
\hline & $(0.06)$ & & $(0.07)$ & \\
\hline \multirow[t]{2}{*}{ Size } & 0.025 & 0.436 & $0.121^{* * *}$ & 0.001 \\
\hline & $(0.03)$ & & $(0.04)$ & \\
\hline \multirow[t]{2}{*}{ EPS } & $0.004^{* *}$ & 0.018 & -0.002 & 0.194 \\
\hline & $(0.00)$ & & $(0.00)$ & \\
\hline \multirow[t]{2}{*}{ Growth } & -0.025 & 0.636 & -0.004 & 0.912 \\
\hline & $(0.05)$ & & $(0.04)$ & \\
\hline \multirow[t]{2}{*}{ LVRG } & 0.049 & 0.785 & 0.291 & 0.168 \\
\hline & $(0.18)$ & & $(0.21)$ & \\
\hline \multirow[t]{2}{*}{ GDP } & $-14.398^{* * *}$ & 0.000 & $-13.781^{* * *}$ & 0.000 \\
\hline & $(1.91)$ & & $(2.05)$ & \\
\hline \multirow[t]{2}{*}{ Constant } & $10.981^{* * *}$ & 0.000 & $10.206^{* * *}$ & 0.000 \\
\hline & $(0.28)$ & & $(0.51)$ & \\
\hline F-Value & $11.552^{* * *}$ & & & \\
\hline $\mathrm{N}$ & 340.000 & & 340.000 & \\
\hline
\end{tabular}

are significance levels at $1 \%, 5 \%$, and $10 \%$ respectively. 
Table 5: Fixed Effect and Random Effect model (Excluding GDP)

\begin{tabular}{|c|c|c|c|c|}
\hline & \multicolumn{2}{|l|}{ MODEL FE } & \multicolumn{2}{|l|}{ MODEL RE } \\
\hline & b/se & p-value & b/se & p-value \\
\hline DY & $\begin{array}{l}-0.266 \\
(0.98)\end{array}$ & 0.788 & $\begin{array}{l}-0.586 \\
(1.03)\end{array}$ & 0.571 \\
\hline PR & $\begin{array}{l}-0.015 \\
(0.09)\end{array}$ & 0.873 & $\begin{array}{l}-0.044 \\
(0.10)\end{array}$ & 0.661 \\
\hline Size & $\begin{array}{l}0.018 \\
(0.04)\end{array}$ & 0.614 & $\begin{array}{l}0.120^{* * *} \\
(0.04)\end{array}$ & 0.002 \\
\hline EPS & $\begin{array}{l}0.003^{*} \\
(0.00)\end{array}$ & 0.052 & $\begin{array}{l}-0.002 \\
(0.00)\end{array}$ & 0.107 \\
\hline Growth & $\begin{array}{l}-0.003 \\
(0.06)\end{array}$ & 0.958 & $\begin{array}{l}0.016 \\
(0.05)\end{array}$ & 0.740 \\
\hline LVRG & $\begin{array}{l}0.107 \\
(0.21)\end{array}$ & 0.608 & $\begin{array}{l}0.355 \\
(0.24)\end{array}$ & 0.133 \\
\hline I & $\begin{array}{l}21.675^{* * *} \\
(6.37)\end{array}$ & 0.001 & $\begin{array}{l}19.568^{* * *} \\
(7.30)\end{array}$ & 0.007 \\
\hline Constant & $\begin{array}{l}7.924^{* * *} \\
(0.70)\end{array}$ & 0.000 & $\begin{array}{l}7.359^{* * *} \\
(0.82)\end{array}$ & 0.000 \\
\hline F-Value & $4.375^{* * *}$ & & & \\
\hline $\mathrm{N}$ & 340.000 & & 340.000 & \\
\hline
\end{tabular}

\section{Conclusion}

Present study examines the relationship between corporate payout policy and market capitalization using sample of 68 firms from nonfinancial sector listed at KSE-100 index for the period of five years through 2006-2010. We used Market Capitalization (MC) as dependent variable, Dividend Yield (DY) and Payout ratio (PR) as independent variable, Size, Earnings per Share (EPS), Growth, Leverage (LVRG), GDP, and Interest (I) as control variables. We applied different statistical techniques of correlation and regression like Pearson's correlation, simple regression model, fixed effect model and random effect model on pooled and panel data to explore the relationship between corporate payout policy and market capitalization. The empirical results suggested that corporate payout policy has strong relationship with market capitalization. Pooled data results showed that measures of corporate payout policy DY has strong negative relationship with market capitalization. It means as dividend yield decrease, market capitalization of the corporations increases which draw the conclusion that investor prefer capital gains in Pakistan (Nazir et al., 2010). Large corporations have high market capitalization. Corporation that uses more debt has high market capitalization. Low earnings per share leads to high market capitalization that shows funds of the companies are invested in profitable projects which sends positive signal in the market, these positive signals result in high market capitalization. Fixed effect model results suggests that EPS, GDP and I have significant relation with MC. DY has negative relation with MC which is insignificant according to fixed effect model. Overall results prove our hypothesis that corporate payout policy has significant impact of market capitalizations of firms in Pakistan.

\section{References}

Abor, J. \& Bokpin, G. A. (2010). Investment opportunities, Corporate finance, and dividend payout policy: Evidence from emerging markets. Studies in Economics and Finance, 27(3), 180-194.

Ahmed, H. \& Javid, A. Y. (2009). The Determinants of Dividend Policy in Pakistan. International Research Journal of Finance and Economics 29, 110-125.

Allen, D. E. \& Rachim, V. S. (1996). Dividend policy and stock price volatility: Australian evidence. Applied Financial Economics, 6(2), 175-188.

Asghar, M., Shah, S. Z., Hamid, K. \& Suleman, M. T. (2011). Impact of Dividend Policy on Stock Price Risk: Empirical Evidence from Equity Market of Pakistan. Far East Journal of Psychology and Business, $4(1), 45-52$.

Asif, A., Rasool, W. \& Kamal, Y. (2011). Impact of financial leverage on dividend policy: Empirical evidence from Karachi Stock Exchange-listed companies. African Journal of Business Management, 5(4), 1312-1324. 
Baker, H. K. \& Powell, G. E. (1999). How Corporate Managers view Dividend Policy. Quarterly Journal of Business and Economics, 38(2), 17-35.

Baker, H. K., Farrelly, G. E. \& Edelman, R. B. (1985). A Survey of Management Views on Dividend Policy. Financial Management, 14(3), 78-84.

Baker, M. \& Wurgler, J. (2004). A Catering Theory of Dividends. The Journal of Finance, 59(3), 1125-1165.

Ball, Ray, Brown, P., Frank, J. F. \& Officer, R. R. (1979). Dividend and the Value of the Firm: Evidence from the Australian Equity Market. Australian Journal of Management, 4, 13-26.

Baskin, J. (1989). Dividend Policy and the Volatility of Common Stock. Journal of Portfolio Managment, 15(3), 19-25.

Bhattacharya, S. (1979). Imperfect Information, Dividend Policy, and The Bird in the Hand Fallacy. The Bell Journal of Economics, 10(1), 259-270.

Black, F. (1976). The Dividend Puzzle. The Journal of Portfolio Management, 2, 5-8.

Conroy, R. M., Eades, K. M. \& Harris, R. S. (2000). A Test of the Relative Pricing Effects of Dividends and Earnings: Evidence from Simultaneous Announcements in Japan. The Journal of Finance, 55(3), 1199-1227.

Diamond, J. J. (1967). Earnings Distribution and the Valuation of the shares: Some Recent Evidence. Journal of Financial and Quantitative Analysis, 2, 15-30.

Easterbrook, F. H. (1984). Two Agency-Cost Explanations of Dividends. The American Economic Review, 74(4), 6550-659.

Fama, E. F. \& French, K. R. (2001). Disappearing dividends: changing firm characteristics or lower propensity to pay? Journal of Financial Economics, 60, 3-43.

Farooq, O., Saoud, S. \& Agnaou, S. (2012). Dividend Policy as a Signaling Mechanism under Different Market Conditions: Evidence from the Casablanca Stock Exchange. International Research Journal of Finance and Economics, 83, 187-198.

Fisher, G. R. (1961). Some factors influencing share prices. The Economic Journal, 71(281), 121-141.

Friend, I. \& Puckett, M. (1964). Dividend and Stock Prices. The American Economic Review, 54(5), 656-682.

Gordon, M. J. (1959). Dividends, Earnings, and Stock prices. The Review of Economics and Statistics, 41(2), 99-105.

Graham, B. \& Dodd, D. L. (1951). Security Analysis: Principles and Techniques (3 ed.). New York: McGraw Hill.

Harkavy, O. (1953). The Relation Between Retained Earnings and Common Stock Prices for Large, Listed Corporations. The Journal of Finance, 8(3), 283-297.

Hussainey, K., Mgbame, C. O. \& Mgbame, A. M. (2011). Dividend policy and share price volatility: UK evidence. The Journal of Risk Finance, 12(1), 57-68.

Imran, K. (2011). Determinants of Dividend Payout Policy: A Case of Pakistan Engineering Sector. The Romanian Economic Journal, XIV(41), 47-60.

Jenson, M. C. (1986). Agency Costs of Free Cash Flow, Corporate Finance, and Takeovers.The American Economic Review , 76(2), 323-329.

Jenson, M. C. \& Meckling, W. H. (1976). Theory of the Firm: Managerial Behavior, Agency Costs and Ownership Structure. Journal of Financial Economics, 3(4), 305-360.

John, K. \& Williams, J. (1985). Dividends, Dilution, and Taxes: A Signalling Equilibrium. The Journal of Finance, 40(4), 1053-1070.

Khan, N. U., Burton, B. M. \& Power, D. M. (2011). Managerial views about dividend policy in Pakistan. Managerial Finance, 37(10), 953-970.

Lease, R., John, K., Kalay, A., Loewenstein, U. \& Sarig, O. (2000). Dividend Policy: Its Impact on Firm Value. Harvard Business School Press Boston, MA.

Litzenberger, R. H. \& Ramaswamy. G. (1982). The Effects of Dividends on Common Stock Prices Tax Effects or Information Effects? The Journal of Finance, 37(2), 429-443.

Miller, M. H. \& Modigliani, F. (1961). Dividend Policy, Growth, and the Valuation of Shares. The Journal of Business, 34(4), 411-433.

Miller, M. H. \& Rock, K. (1985). Dividend Policy Under Asymmetric Information. Journal of Finance, 40, 1031-1051.

Miller, M. H. \& Scholes, M. S. (1978). Dividend and Taxes. Journal of Financial Economics, 6, 333-364.

Naceur, S. B., Goaied, M. \& Belanes, A. (2006). On the determinants and dynamics of dividend policy. International Review of Finance, 6(1), 1-23.

Naeem, S. \& Nasr, M. (2007). Dividend Policy of Pakistani Firms: Trends and Determinants. International Review of Business Research Papers, 3(3), 242-254. 
Nazir, M. S., Nawaz, M. M., Anwar, W. \& Ahmed, F. (2010). Determinants of Stock Price Volatility in Karachi Stock Exchange: The Mediating Role of Corporate Dividend Policy. International Research Journal of Finance and Economics, 55, 100-107.

Nishat, M. (1992). Share Prices, Dividend and Retained Earnings Behaviour in Pakistan Stock Market. The Indian Economics Journal, 40(2), 57-65.

Nishat, M. \& Irfan, C. M. (2003). Dividend Policy and Stock price Volatility in Pakistan. Paper presented at 11th Pacific Basin Finance, Economics and Accounting Conference.

Okpara, G. C. (2010). A Diagnosis of the Determinant of Dividend Pay-Out Policy in Nigeria: A Factor Analytical Approach. American Journal of Scientific Research, 8, 57-67.

Rashid, A. \& Rehman, A. A. (2008). Dividend Policy and Stock Price Volatility: Evidence from Bangladesh. Journal of Applied Business and Economics, 8(4), 71-80.

Rozeff, M. S. (1982). Growth, Beta and Agency costs as determinants of dividend payout ratios. The Journal of Financial Research, 3, 249-259.

Scott, D. F. \& Martin, J. D. (1975). Industery Influences on Financial Structure. Financial Management , 6773 